\title{
The Influence of Teacher Work Motivation and the Leadership of Schools on Teacher Performance
}

\author{
Susi Herawati $\left.{ }^{1 *}\right)$, Yasir Arafat ${ }^{2}$, Tri Widayatsih ${ }^{2}$ \\ ${ }^{1} \mathrm{SD}$ Negeri $03 \mathrm{OKU}$ \\ 2Universitas PGRI Palembang \\ *Corresponding author. E-mail: susiharyono18@gmail.com
}

\begin{abstract}
This study aims to find the influence of teacher work motivation and principal leadership on teacher performance. The research was carried out at the Ki Hajar Dewantara Cluster II Elementary School, East Baturaja District. This type of research is quantitative research. While the research method used is the method of partial and simultaneous correlation. The sample in the study was the teachers of the Cluster II Ki Hajar Dewantara Elementary School, East Baturaja District, totaling 86 people. The data collection technique used a questionnaire. According to the findings of this report, teacher work motivation has an effect on teacher success, implying that Ho is rejected and Ha is accepted. As a result, teacher job encouragement may have an effect on teacher success. The principal's leadership has an effect on teacher results, so Ho is rejected and Ha is accepted. As a result, teacher job encouragement may have an effect on teacher success. Teacher encouragement and principal leadership have an effect on teacher performance. The coefficient of determination R2 (R Square) is 0.16 , indicating that the variables of teacher job motivation (X1) and principal leadership (X2) will affect teacher output (Y) concurrently with a contribution of $16.00 \%$, while the remaining $84.00 \%$ is clarified by factors not included in this analysis.
\end{abstract}

Keywords: Teacher Work Motivation, Principal Leadership, Teacher Performance

\section{INTRODUCTION}

Education is the basic capital for creating superior and competent human resources. Schools are formal educational institutions that play an important role in improving education quality through learning in order to help generate superior human capital, which are the most important requirements for the development of an advanced and civilized nation and country. Regardless of the amount of natural resources owned by a country, as well as the capital and infrastructure available, in the end only in the hands of reliable human resources the development targets of the nation and state will be achieved. In view of thinking like this, a nation will not be able to achieve progress without a well-organized educational system.

One of the government's efforts to support the implementation of this law is by increasing the qualifications of teacher education through an equalization program in which elementary school teachers have at least a Bachelor's degree (Strata 1). These efforts are still complemented by various training and upgrading and teacher certification. This effort is made as an indication that there is still a need to improve teacher performance with the aim of teachers in carrying out their duties to be more professional in their fields. The government until now has continued to encourage teacher linearization to improve the quality of education. Through the Regulation of the Minister of Education and Culture Number 16 of 2019 concerning the Linear Arrangement of Certified Educator Teachers, the The government hopes that teachers' roles in carrying out their responsibilities as educators will become more professional in the future.

Through this regulation, it is also expected that the number of teachers who are linear in accordance with their education sector will increase, this will certainly affect teacher performance. Teachers are the most important factor in raising educational standards. One of the most important requirements for achieving highquality education is the presence of trained and experienced teachers. A teacher who has high performance will have a positive attitude towards the work he is facing, such as discipline, working seriously, improving work quality, being responsible, highly dedicated and so on. The importance of teacher performance plays a very important role in improving 
the success of education, so it is necessary to make efforts so that teachers have high performance.

This is in accordance with the fact that performance is described as employee work activity in which employees collaborate with others both within and outside the unit with the goal of improving employee work effectiveness, sharing knowledge and resources, forming productive working relationships, reaching consensus, and constructively managing conflict. The success of a job is primarily measured by one's ability to perform. Furthermore, [1] argues that motivation is a state that encourages an individual's desire to carry out certain activities to achieve his desires.

Work motivation can also affect a person's performance. Teacher work motivation is closely related to work productivity, both those related to the academic field and those related to administrative and service to students [7], [8], [9]. Therefore, a teacher must have high motivation in order to carry out his duties properly. According to [7], education is a type of total human interaction that leads to full human growth, and it is a continuous process that is often accompanied by efforts. Development of Human Resources. This purpose is realized in the principal's efforts to administer education, both in preparing, coordinating, implementing, supervising, and managing education in schools, in its implementation in schools [10].

To achieve this goal it is necessary to apply a management system that allows the realization of educational success. The main school resource that is very important in developing the quality of schools is the teacher, in which case a teacher has a very large duty and role to optimize the potential of students. . The principal is required to be able to develop various potentials and abilities both in terms of managerial aspects in managing school resources according to the ability of the principal and needs.

school. The role of the principal as a leader is the key to improving or developing the school. Increasing the performance of teachers and employees in learning will be achieved if the principal as a leader is able to spur teachers and employees to improve their performance seriously and with high dedication to the tasks they carry. Principal leadership is one of the factors that influence teacher performance. The application of the right leadership style of the principal will have a significant influence in decision making, as well as in influencing teachers to do work more efficiently and effectively to achieve good teacher performance.

In relation to the Principal's leadership, [2] argues that in an organisation, the leadership aspect is critical because the leader can move and guide the organization toward its goals, which is a difficult task because you must understand any particular subordinate's actions..
Some teachers experience difficulties in making syllabus and lesson plans, lack of discipline that is emphasized on teachers such as teachers arriving late and delaying class for various reasons, using learning methods and strategies, compiling evaluation tools, classroom management activities, and lack of ability in determine the approach and ways of evaluation in the teaching and learning process.

So far, Teachers and staff of these schools are not doing well, where there are still some teachers and employees who are less professional and responsible in carrying out their duties as teaching and education personnel. This of course requires the role of a leader who is able to control well, to become a motivator for teachers and employees so that they can be more professional in carrying out their duties and responsibilities. Therefore it takes the role of the principal as a leader in an educational institution, namely as a motivator and is expected to be able to control all teachers in Gugus II Ki Hajar Dewantara, Baturaja Timur District, Ogan Komering Ulu Regency. Another fact that researchers have observed in the field is that the leadership of the principal has not been able to fully influence, mobilize, develop and empower teachers to be able to increase work motivation and performance, the principal has not routinely conducted classroom supervision, to see directly the teacher implementing his learning, is limited time to provide guidance and provide assistance to teachers in making syllabus and lesson plans. If work motivation is still low and school leadership that has not been effective continues, it is not impossible that it will have an impact on the quality of primary school education in Cluster II Ki Hajar Dewantara, East Baturaja District, Ogan Komering Ulu Regency.

\section{METHODS}

This research uses quantitative research methods that examine facts that have occurred and all data and information are presented in the form of numbers. $[4],[5],[6]$ stated that quantitative research is one of the research methods that tests the hypothesis and examines the theories with parametric statistical analysis. The subjects in this study were all teachers in Cluster II Ki Hajar Dewantara, East Baturaja District, Ogan Komering Ulu Regency, totaling 110 people. To collect the data, researchers used a questionnairee. The data analyses were using simple statistics calculation and SPSS software program. 


\section{RESULTS AND DISCUSSION}

\section{a. Effect of Teacher Work Motivation (X1) on Teacher Performance (Y)}

The results showed that teacher work motivation (X1) had an effect on teacher performance (Y). The results of the t-test statistical analysis above showed that the t-test value was 2.182 with a significance value of 0.05 with t-table 1.988 or in other words, tcount 2.182> ttable 1.988. The results of this study are in line with the results of research conducted by Mulyadi (2020) conducted a research at SMP Negeri 3 Prabumulih to see if teaching skills and job motivation have an impact on teacher efficiency, either individually or in combination. Similar results were obtained from the results of the research conducted by Destiniar et al. In 2020, a study was conducted with the aim of determining the impact of teacher certification and job motivation on teacher performance. The sample for this analysis was the entire population of 94 teachers who had been certified at the State Junior High School in Kertapati District, Palembang. The descriptive quantitative approach was used in this study to provide answers to the research problem's formulation. As a result, the primary data in this analysis is numbers. Questionnaires, observation, reporting, and literature review are all examples of data collection techniques. The findings revealed that teacher certification and work motivation had a positive effect on teacher performance, and that teacher certification and work motivation had a positive effect on teacher performance.

\section{b. The Effect of Principal Leadership (X2) on Teacher Performance (Y)}

The results showed that the principal's leadership (X2) had an effect on teacher performance (Y). These results support the hypothesis that the principal's leadership affects the performance of teachers in Cluster II Ki Hajar Dewantara, East Baturaja District, Ogan Komering Ulu Regency. The results of the t-test statistical analysis above obtained the t-test value of 2.182 with a significance value of 0.05 with t-table 1.988 or in other words tcount $2.182>$ ttable 1.988 . The results of this study are in line with the research results. Fitria et al about the influence of work environment and work motivation on the performance of high school teachers in Muara Padang District. According to the findings of this report, the work environment and motivation of high school teachers in Muara Padang district have a positive and important impact on their success. c. Effect of Work Motivation and Principal Leadership (X2) on Teacher Performance (Y)

The results showed that the principal leadership (X2) had a joint effect on teacher performance (Y). Anova test results in table 4:12 note that the value of Fcount 9,078, and obtained Ftable 1.41. Then Fcount 9,078> Ftable 1.41, so it can be concluded that teacher work motivation (X1) and principal leadership (X2) jointly influence teacher performance (Y). The results of this study are in line with the results of research by [3] concerning the influence of principal leadership and work motivation on teacher performance. The results showed that there was a significant influence between principal leadership and work motivation on teacher performance, there was a significant influence between work motivation. on performance

\section{CONCLUSION}

In conclusion, teacher work motivation affects teacher performance in Cluster II Ki Hajar Dewantara, East Baturaja District, Ogan Komering Ulu Regency, principal leadership affects teacher performance in Cluster II Ki Hajar Dewantara, East Baturaja District, Ogan Komering Ulu Regency, and teacher work motivation and principal leadership jointly affect teacher performance in Cluster II Ki Hajar Dewantara, East Baturaja District, Ogan Komering Ulu Regency.

\section{REFERENCES}

[1] Sunyoto, D. 2013. Manajemen dan Pengembangan Sumber Daya Manusia. Yogyakarta. PT. Buku Seru

[2] Sutrisno, E. (2014). Manajemen Sumber Daya Manusia. Jakarta. Kencana

[3] Eddy. (2020). Pengaruh Kepemimpinan Kepala Sekolah dan Motivasi Kerja terhadap Kinerja Guru. Journal of Innovation in Teaching and Instructional Media Vol. 1 No. 1, September 2020 Page: 46-57

[4] Creswell, J. W. (2014). Research Design, Qualitatives, Quantitative, and Mixed. Methods Approcahes (Fourth Edition). United State of America: Sage.

[5] Sugiyono. 2014. Metode Penelitian Pendidikan Pendekatan Kuantitatif,. Kualitatif, dan R\&D. Bandung: Alfabeta.

[6] Ary, D., et al.. (2010). Introduction to Research in Education. Canada.

[7] Alimohammadi \& Neyshabor. 2013. Work motivation and organizational commitment among Iranian employees. International Journal of Research in Organizational Behavior and Human Resource Management, 1(3), 1- 12.

[8] Akinyemi, B.O. (2014). Organizational commitment in Nigerian banks: The influence of 
age, tenure and education. Journal of Management and Sustainability, 104-115.

[9] Amirabad, F.N, Sohrabi, N., \& Samani, S. (2014). Relationship between organizational justice, work conscience and organizational commitment of personnel's of gas company in Yasouj. Kuwait Chapter of the Arabian Journal of Business and Management, 3(8), 74-82.

[10] Adey, N.H \& Bahari, F. (2010). Hubungan antara kecerdasan emosi, kepuasan kerja dan komitmen terhadap organisasi (correlation between emotional intelligence, work performance and commitment toward organization). Jurnal Kemanusiaan, 16. 6282 